\title{
THE PROVENANCE OF NEO-BABYLIONIAN LEGAL DOCUMENTS FROM 'KISH' OUTSIDE THE ASHMOLEAN MUSEUM COLLECTION*
}

\author{
POCHODZENIE NOWOBABILOŃSKICH DOKUMETÓW \\ PRAWNYCH Z „KISZ” Z KOLEKCJI W MUZEUM ASHMOLEAN
}

\author{
Stanisław Chmielowski \\ orcid.org/0000-0003-0176-1365 \\ Instytut Historii, Uniwersytet im. Adama Mickiewicza w Poznaniu. \\ ul. Uniwersytetu Poznańskiego 7, 61-614 Poznań \\ stanislaw.chmielowski@amu.edu.pl
}

\begin{abstract}
The majority of currently known Neo-Babylonian legal and administrative documents from Kish come from excavations held on this site by the joint expedition of Oxford - Field Museum (Chicago) between 1923-1933. They are now housed in the Ashmolean Museum, Oxford. However, ca. 40 Neo-Babylonian 'Kish' tablets, i.e., written in Hursagkalamma or Kiš, are present in other collections. How did they end up in these museums assuming that most of them was acquired in the last quarter of the $19^{\text {th }}$ century, 30-50 years before the expedition mentioned above? I suppose that they were not found in Kish, even though their Ausstellungsort indicates quite the opposite. They instead come from nearby Babylon or Borsippa cities. The analysis conducted in the article seems to confirm this assumption, and for most cases, the provided attribution should be considered. Additionally, tablets under discussion are testimonies of the vivid economic life of entrepreneurial Babylonians in the first millennium BC.
\end{abstract}

KEY WORDS: Neo-Babylonian period, Neo-Babylonian economy, archival studies, museum collections, Kish, Kiš, Hursagkalamma, Babylonia Babylon Borsippa

* ORCID: https://orcid.org/0000-0003-0176-1365. I would like to thank Christopher Walker for sharing crucial data from yet unpublished catalogues CBT 4 and CBT 5. John P. Nielsen kindly provided me with his transliteration of BM 122180. I would also like to express my deepest gratitude towards Aleksandra and Zygmunt Podhorodecki for their hospitality during my stay in London. 
The majority of currently known Neo-Babylonian legal and administrative documents from Kish come from excavations held on this site by the joint expedition of Oxford University and Field Museum (Chicago) between 1923-1933 (Moorey, 1978) ${ }^{1}$. Tablets unearthed then are part of the Ashmolean Museum collection, Oxford. They were published as copies together with other Late Babylonian texts in this collection in 1984 by Gilbert J. P. McEwan.

In this paper, I would like to discuss a particular group of ca. 40 tablets which have been drafted in Hursagkalamma or Kiš but are now part of several collections outside the Ashmolean Museum. My initial interest in texts under discussion was hooked by the fact that various museums acquired them in the last quarter of $19^{\text {th }}$ century, i.e., 30-50 years before Oxford-Field expedition. Such issue raised the following question: is Kish their actual findspot?2 .

That some 'Kish' tablets could probably originate from sites different from the area of Kish itself has been suggested a few times recently:

- "BM 94878 [place of issue: Kiš] belongs to a Borsippa collection so it was probably found on that site rather than in Kish" (Waerzeggers, 2003-2004, p. 166);

- "The fact that BM 46799+ [place of issue: Kiš] became part of the Rassam collection, most of which come from Babylon and Dilbat, even raises the possibility that Bēl-êtir, or another holder of that tablet, made his way to Babylon" (Nielsen, 2010, p. 104);

- "Ergänzend zu den Texten der britisch-amerikanischen Ausgrabungen sind nur eine Handvoll weiterer Texte aus Kiš bekannt. Zwei Texte befinden sich heute in den Sammlungen des British Museum, i.e. BM 40706 [place of issue: Hursagkalamma] und 114709 (= Fs. Walker 124) [place of issue: Hursagkalamma]. Der erste dieser beiden Texte, der der Sammlung 81-4-28 angehört, stammt aus H. Rassams Ausgrabungen in der zweiten Hälfte des 19. Jahrhunderts. Anzunehmen ist daher, dass der Text zwar in Kiš ausgestellt, aber im nahegelegenen Babylon gefunden wurde“ (Hackl, 2013, vol. 1, p. 540);

${ }^{1}$ In general, the name 'Kish' (i.e., English phonological record of the proper Sumerian name 'Kiš') describes the whole archaeological site consisting of ca. 40 mounds, $12 \mathrm{~km}$ east from Babylon. As far as the Neo-Babylonian period is concerned, this site consists of two major parts: a city of Kiš to the west and a city of Hursagkalamma to the east. Kiš - from which this site took its name - is settled on a few mounds around Tell Uhaimir in the western part of the Kish area while Hursagkalamma was located in the eastern part of the Kish area with a centre on Tell Inghara. Even in antiquity this closeness led to treating these two places as a kind of a twin-city (germ. Doppelstadt) with Kiš as a dominant element in this pair even though it was Hursagkalamma which in fact had more numerous population and thrived in the first millennium BC while western part of the Kish area was almost deserted (Gibson, 1972, p. 4; Moorey, 1978, p. XX). It is stressed that hur.sag.kalam.ma.ki is not an alternative name of kiš.ki, contrary to e.g., e.ki, ká.dingir. ra.ki, and tin.tir.ki which all three refer to the same city, i.e., Babylon.

2 There were a few organized expeditions before Oxford-Field mission but - according to preserved documentation - none of them brought to light any Neo-Babylonian legal documents (Moorey, 1978, p. 7-13). Even though there is some evidence that the area of Kish was a subject to clandestine excavations before the 1900's I suppose that, as far as Neo-Babylonian tablets are concerned, Kish is not the place where they had been unearthed. 
- "The economic activities of Ishunnatu in Kiš continue during the beginning of Darius' reign as shown in two other texts drafted in Hursagkalamma but probably found in Babylon within the Egibi archive CTMMA 3, 65 and BM 30948 [...] Except text OECT 10, 239, all the other texts belong to the Egibi Archive found in Babylon. The Egibis keep and control all the transactions contracted by Ishunnatu" (Tolini, 2013) .

In this paper I would like to re-examine provenances of the Neo-Babylonian 'Kish' tablets from outside the Ashmolean Museum collection and show that based on both external and internal criteria these tablets - despite being drafted in Hursagkalamma or Kiš - were not unearthed in the Kish area but that they instead come from nearby Babylon or Borsippa. Additionally, a short outline of the content of all texts under discussion will also shed some light on intercity relations in the first millennium BC Babylonia.

\section{THE PROVENANCE OF 'KISH' TABLETS}

Sadly, the archaeological context of most of the Neo-Babylonian archives is unknown, with only a few of them having at least some hints to their exact provenance and findspot. The majority of cuneiform tablets was unearthed during clandestine or poorly documented excavations ${ }^{4}$. Antiquarians have caused further commotion as tablets presumably originating from a single archive had been mixed on the market and eventually reached various destinations ${ }^{5}$. It does not mean, however, that we are left blindfolded while tracking their origin. Careful analysis of both external (scarce 'archaeological' data ${ }^{6}$, museum collection's register) and internal (place of issue, prosopography, other traces in the text) criteria might provide a much-needed background to the archival studies. The complex process of (re)constructing an archive - or what we presume once formed it - was outlined by Heather D. Baker (2004, p. 5-8). Here I will follow these footsteps in an attempt to establish provenance of not a singular archive but the particular group of tablets linked by their common place of the issue, which is Hursagkalamma or Kiš.

${ }^{3}$ To find a different example of similar phenomena, one could add the case of two texts, in fact, duplicates, issued in Humaděš in Persia but presumably found within the Egibi archive in Babylon: Camb. 388 and OECT 10, 131 (Stolper, 1990, p. 170). For the localisation of Humadēšu see: Stolper, 1984, p. 306-307.

${ }^{4}$ Well-documented Koldewey's excavations in Babylon (1899-1917) are a remarkable exception (Pedersén, 2005). Jursa 2005 serves as a comprehensive guide to what we know about provenance of all currently recognised Neo-Babylonian archives.

5 The Egibi family archive scattered among several western collections is a prominent example. The main part of the archive is in the British Museum, and even there, it is spread among acquisitions of at least five years, i.e., 1876-1881 (Wunsch, 2000a/1, p. 2, n. 5-6; Jursa 2005, p. 65, n. 415).

${ }^{6}$ This data is not strictly archaeological per se. These are mostly mere indications as to on which site particular collection has been unearthed. 
As indicated by Baker, a prime step of reconstructing an archive - when archaeological data is missing - is to assemble tablets joint by their prosopography. Each archive had its protagonist(s) and prominent figure(s). When prosopographical links were established, and the archive's core emerged, another thing to do is to figure out its provenance. The commonly used method is to analyse places of issues of its tablets ${ }^{7}$. Place of issue, ger. Ausstellungsort, is the inherent element of the Neo-Babylonian legal texts. It usually immediately precedes a date and, as such, is easy to localise. If we know that the majority of tablets was drafted in one city, then we may suppose that this settlement is the place from which they come. This method based on a reasonable assumption - works for numerous text groups but fails to be valid when tracking singular tablets. One cannot merely presume then that a place of issue is identical with a provenance as a movement of goods and people - and therefore also tablets - has to be acknowledged (e.g., Jursa, 2010, p. 114-115, 123125). One could also add an undeniable fact that we know hundreds of toponyms where texts were drafted (Zadok, 1985). However, there are much fewer settlements recognised, and the vast majority of currently known Neo-Babylonian cuneiform tablets, in fact, come from a few sites. We should always have wider scope in mind and search for an archival attribution of a tablet whenever it is possible. One cannot detach the tablet from its archive as the archival approach is the best method of establishing provenance of a tablet when archaeological data is missing. Needless to say, an analysis of a particular tablet can only reach its full value when such document will be evaluated within a broader context of its archive and furthermore, its archive within its socio-economic and historical reality (CTMMA 3, p. XIV-XIX; Waerzeggers, 2018, p. 89-92).

To solve the question of the provenance of 'Kish' tablets outside the Ashmolean Museum collection, I will firstly inquire external criteria, i.e., data from museum collections' registers. Secondly, I will search for the archival attribution of each document. This 'double-check' should lead to the firm establishment of the provenance of each tablet ${ }^{8}$.

${ }^{7}$ For a recent work with an elaborated explanation of archive's reconstruction see: Frame, 2013, p. $7-14$.

${ }^{8}$ It is to be stressed that Ausstellungsort does not mean the same thing as provenance. It is not my intention to undermine veracity of a 'place of issue' of a tablet. If the text states that a tablet was written in a particular city, it should be taken for granted that indeed it was drafted there. Place of issue of a document and its provenance are two different things. E.g., a text written in Babylon (Ausstellungsort) could have been found in Ur (provenance), but it does not mean that its place of issue any less significant (see e.g. Sîn-uballit archive was found in Ur but texts were written in Babylon, Jursa, 2005, p. 135-137). An 'action' of such a document took place in Babylon and its 'actors' (i.e., contractors and witnesses) were there while drafting. Finding such text in Ur does not make it any less valuable in reconstructing a socio-economic reality of Babylon, nor it loses its importance in analysing activities of the inhabitants of Ur. 


\section{Solving the case: external criteria}

Altogether, there are 36 tablets drafted in Hursagkalamma or Kiš and housed outside the Ashmolean Museum. They are in six museum collections. The majority of them, i.e., 29, are in the British Museum. Metropolitan Museum of Art and Vorderasiatisches Museum have two tablets each while Birmingham Museum and Art Gallery, Royal Ontario Museum, and Yale Babylonian Collection each hold a single tablet.

Table 1. The number of tablets drafted in Hursagkalamma or Kiš hand housed outside the Ashmolean Museum

\begin{tabular}{|l|c|}
\hline \multicolumn{1}{|c|}{ Collection } & No. of tablets \\
\hline Birmingham Museum and Art Gallery & 1 \\
\hline British Museum & 29 \\
\hline Metropolitan Museum of Art & 2 \\
\hline Royal Ontario Museum & 1 \\
\hline Vorderasiatisches Museum & 2 \\
\hline Yale Babylonian Collection & 1 \\
\hline Summary & 36 \\
\hline
\end{tabular}

Of all collections listed above the British Museum's gives us the most helpful hints regarding the provenance of tablets under discussion. Its registers, apart from giving the name of tablets' providers (either by purchase or excavations ${ }^{9}$ ), occasionally also mention the provenance of each group of tablets as noted by the Trustees during their acquisition.

'Kish' tablets in the British Museum are spread among 15 separate acquisitions. Each one of them represents a group of texts acquired on the very same day from the very same person (e.g., accession No. ' $76-11-17, \mathrm{X}$ ' means, that tablet No. X was acquired on the $17^{\text {th }}$ of November 1876). Their accession numbers are as follows: 7611-17, 194, 250, 348, 356, 675, 773, 880, 1036, 1090, 1628, 1648, 1779; 77-4-17, 5, 12; Sp.521; 79-7-30, 33; 81-4-28, 251; 81-6-25, 40; 81-7-1, 341; 81-8-30, $265+394$ + 831; 84-2-11, 111, 115; 88-4-19, 12, 21; 98-5-14, 469; 99-4-15, 347; 1901-10-12, $531 ; \mathbf{1 9 2 0 - 1 2 - 1 3}, 1 ; \mathbf{1 9 3 0 - 7 - 2 5}, 2$. Underneath I present what we can learn from relevant British Museum registers ${ }^{10}$ :

\footnotetext{
9 Note, however, that even during excavations some occasional purchases were made which could 'corrupt' such collection.

10 Detailed descriptions of 76-11-17, 77-4-17, Sp. (I), 79-7-30, 80-6-17, 81-4-28, 81-6-25, 81-7-1, and 81-8-30 collections were possible thanks to the courtesy of Christopher Walker who kindly shared re-
} 
- 76-11-17: purchased by George Smith in Baghdad in 1876 from the Italian dealer Michael Marini; ca. 2600 items; register gives the provenance as 'Babylon' to almost all items from this collection (exceptions are as follows: No. 121-125 'Babylonia'; No. 2413-2417 'Assyria'; No. 145-150 and No. 2611-2627 no provenance); majority of legal tablets in this acquisition constitute what is now called 'the Egibi archive'; all of our tablets, i.e. No. 194, 250, 348, 356, 675, $773,880,1036,1090,1628,1648$, and 1779, fall into the provenance 'Babylon' (Jursa, 2005, p. 65; Panayotov and Wunsch, 2014; Wunsch, 2000a, vol. 1, p. 1-2);

- 77-4-17: purchased from Joseph Mordecai Shemtob in London; 20 items; register gives the provenance 'Babylon' to all tablets;

- Sp.: purchased from Messrs. Spartali \& Co. in London in April 1879; ca. 650 items; register gives the provenance 'Babylon' to No. 1-376 and No. 536 (with the exception of No. 188 as 'Kouyunjik'), 'Babylonia' to No. 377-504 and 537-652; no provenance registered for No. 505-535; our tablet with No. 521 has thus no provenance but based on the fact that tablets from this range have joins to the tablets from Babylon in the very same collection ${ }^{11}$ and that astronomical texts from Esagila (based on internal evidence), the main temple of Babylon, are also present here, i.e., between No. 505-535, this city presumably is its provenance (Clancier, 2009, p. 188; Neugebauer, 1955, p. 5-6);

- 79-7-30: purchased from J. M. Shemtob in London; 54 items; register gives the provenance 'Babylonia' to No. 1-18, and 'Babylon' to No. 19-54, therefore our tablet with No. 33 comes from Babylon;

- 81-4-28: excavated by Hormuzd Rassam; ca. 1000 items; tablets from Babylon, Borsippa (Birs Nimrud), and Sippar (Abu Habba); provenance of our tablet with No. 251 is given as 'Jimjima'; Jimjima (or Jumjuma and other variant writings) is a modern name of the village in the southern part of Babylon (see: also CBT 6, p. XXX-XXXI);

- 81-6-25: purchased from Messrs. Spartali \& Co. in London; although registered in June 1881 it has been in the city since the middle of 1879 (van Driel, 1989, p. 110); ca. 880 items; register gives the provenance as 'Baby-

\footnotetext{
levant data from yet unpublished catalogues CBT 4 and CBT 5. I am also indebted to him for information regarding two further British Museum's collections, i.e., 1901-10-12, and 1920-12-13.

${ }^{11}$ E.g., Sp. 535 joins three fragments: one from 'Babylon', Sp. 189, and two from 'Babylonia', Sp. 541 and Sp. 564. There was some confusion while packing the tablets. It also strengthens the impression of mixing the tablets while circulating on the market. However, major acquisitions to some extent still should reflect original findings, as M. Jursa put it: „Da aufgrund der großen Anzahl von Tafeln ein signifikanter Prozentsatz von zusammen Gefundenem oder Erworbenem trotz der eher sorglosen Fundaufnahme- und Verpackungspraktiken zusammen verschickt worden sein muß, ist die Gruppierung und Reihung der Tafeln in der Sammlung ein - zugegebenermaßen unscharfer - Reflex der ursprünglichen Fundkomplexe“ (1999, p. 4). Note that, as P. Clancier observed, M. Marini, J. Shemtob, and Messrs. Spartali \& Co. probably had the same source of supply. Therefore there are numerous joins between collection acquired from them (2009, p. 188).
} 
lonia' to No. 1-596 and 749-882, 'Abu Habba' to No. 597-748; our tablet with No. 40 was registered under a broad term 'Babylonia'; there are ca. 90 legal documents in range No. 1-596 with preserved place of issue; ca. 70 of them have been drafted in Babylon and further ca 20 documents have been issued elsewhere but at least five of them are related to the Egibi archive and thus were unearthed in Babylon ${ }^{12}$; additionally, there are over 140 astronomical texts which originated in Esagila (based on internal evidence); thus, it is possible - but in no means certain - that our tablet's provenance is also Babylon (Clancier, 2009, p. 185-195);

- 81-7-1: excavated by H. Rassam; ca. 3400 items; tablets from 'Babylon', 'Borsippa', 'Geraineh' (20 km North from Babylon), 'Cutha', and 'Sippar'; sadly, register gives no provenance to the vast majority of tablets and our tablet No. 341 is among them; there are a few tablets issued in Babylon but majority of tablets come from Sippar, so one cannot exclude this attribution either (see also: Jursa, 1999, p. 4-6);

- 81-8-30: excavated by H. Rassam; ca. 950 items; majority of the collection has no provenance but when it occurs tablets are from 'Babylon' or 'Dailem' (ancient Dilbat); our tablet is a join of three fragments: No. 265, 394, and 831; first two are from 'Babylon' and the third fragment has no provenance but thanks to the join it is obvious that all three fragments have to come from Babylon (see also: CBT 6, p. XXXI-XXXII);

- 84-2-11: purchased from Messrs. Spartali \& Co. in London; ca. 590 items; mostly Neo-Babylonian tablets; according to register they come from 'Sippar, Babylon, Cutha and Dilbat' but tablets do not have any specific provenances given; there are over 200 legal documents in this collection and based on the available data (CBT 8, p. 97-113; Baker, 2004; George and Bongenaar, 2002, p. 134-136, all three complemented by available copies of the tablets) majority of them have been drafted in Babylon ${ }^{13}$, however other sites like Dilbat cannot be entirely discarded ${ }^{14}$; Sippar material is presumably limited only to the administrative texts ${ }^{15}$ (CBT 8, p. XIII);

- 88-4-19: seller unknown; 26 items; mixture of Neo-Babylonian texts from different genres; apart from our tablets with No. 12 and 21 issued in Kiš, two tab-

12 There are also at least 10 texts without preserved place of issue which are also from the Egibi archive.

13 Note that slightly over 50 tablets from this collection are part of the Nappāhu archive which, based on internal evidence, comes from Babylon (Jursa, 2005, p. 68-69; see: Baker, 2004 for the edition of the whole archive). There are also many tablets from the Ëpeš-ilī A archive which, based on internal evidence, also comes from Babylon (Jursa, 2005, p. 62-64).

14 I was able to identify ca. 105 legal documents with the preserved place of issue. Ca. 75 drafted in Babylon, ca. 25 in different smaller settlements (notice six tablets from Harrān-Kiš), and at least five tablets issued in Dilbat. There is also at least one document for Borsippa, i.e., 84-2-11, 8 (BM 77281; Nbk. 436).

15 However, note a loan of silver 84-2-11, 11 (BM 92788; Nbk. 45) drafted in Sippar. 
lets drafted in Babylon and one in Sippar; there is also one join to a tablet from 80-6-17 collection (88-4-19, $17+80-6-17,442)$; the latter collection of ca. 1900 items was excavated by H. Rassam; register gives the provenance 'Babylon' to all but nine of its items; although one cannot make the conclusion in regard to our tablets No. 12, and 21, Babylon is tempting (CBT 8, p. XIV; for 80-6-17 see also: CBT 6, p. XXX);

- 98-5-14: purchased from S. A. Turabian in Constantinople; ca. 760 items; no provenances recorded; this acquisition consists of two distinct parts; first of a few hundred tablets comprises tablets from Lagash dated to the Third Dynasty from Ur; second is a group of ca. 150 Neo-Babylonian tablets drafted in Borsip$\mathrm{pa}$ - in fact this collection marks 'the beginning of the exploitation of Borsippa by Baghdad dealers' (CBT 3, p. IX); based on the homogeneity of places of issue of these tablets it is to be assumed that they indeed all come from Borsippa (CBT 3, p. 94-127);

- 99-4-15: purchased from the French dealer Isaac Elias Gejou in Paris; ca. 780 items; no provenances recorded; apart from a few hundred tablets dated to the Third Dynasty of Ur from Lagash and Umma, and Old Babylonian tablets from Kisurra, Larsa, Sippar, and Uruk, there are ca. 40 Neo-Babylonian documents drafted in Borsippa, four tablets drafted in Babylon and a few tablets from other sites; based on the majority of the Neo-Babylonian corpus in this collection and the earlier acquisition purchased from Gejou, i.e. 98-5-14, Borsippa should be regarded as the provenance of these tablets (CBT 3, p. 248-276);

- 1901-10-12: purchased from I. E. Gejou; ca. 1400 items; no provenances recorded; for what can be said about the Neo-Babylonian tablets is that (nearly?) all of them have been drafted in Borsippa ${ }^{16}$;

- 1920-12-13: purchased from I. E. Gejou; ca. 150 items; no provenances recorded; collection comprised of Neo-Babylonian legal and administrative texts; tablets drafted in Babylon, Sippar, and Uruk; conclusion as to the provenance of our tablet with No. 1 is not possible;

- 1930-7-25: purchased from Mrs Daphne Harpur; three items; small acquisition of just two tablets and one cylinder seal; despite its number, i.e., 1930-7-25, collection was actually acquired in July 1931, not in 1930; No. 1 is a cylinder seal from Girsu dated to the last quarter of the $3^{\text {rd }}$ millennium BC; No. 3 is a tablet dated to the Third Dynasty of Ur and has no provenance; our tablet No. 2 also does not have the registered provenance; the date of the acquisition makes it possible that this tablet was excavated in Kish during Oxford-Field mission, but it is far from certain ${ }^{17}$.

\footnotetext{
16 See also: Waerzeggers 2003/2004, p. 166 who names this acquisition as a 'Borsippa collection'.

17 Information taken from the British Museum online collection site: https://www.britishmuseum. org/research/collection_online/search.aspx [Accessed: June 20, 2019].
} 
Table 2. Hursagkalamma/Kiš texts' acquisition information as taken from the British Museum's registers. Names in brackets indicate a presumed provenance. See descriptions for details

\begin{tabular}{|c|c|c|c|}
\hline Accession No. & Text & $\begin{array}{l}\text { Purchased from/ } \\
\text { Excavated by }\end{array}$ & Provenance \\
\hline $\begin{array}{l}76-11-17,194 \\
250 \\
348 \\
356 \\
675 \\
773 \\
880 \\
1036 \\
1090 \\
1628 \\
1648 \\
1779\end{array}$ & $\begin{array}{l}\text { Camb. } 331 \\
\text { Wunsch } 1997 / 1998, \\
\text { No. } 12 \\
\text { BM } 30621 \\
\text { Abraham } 2004 \text {, No. } 17 \\
\text { BM } 30948 \\
\text { Camb. } 330 \\
\text { Nbk. } 346 \\
\text { AOATS 4, No. } 77 \\
\text { BM } 31363 \\
\text { Camb. } 393 \\
\text { Wunsch } 1997 / 1998, \\
\text { No. } 10 \\
\text { Dar. } 232\end{array}$ & $\begin{array}{l}\text { G. Smith } \\
\text { (purchased by) }\end{array}$ & Babylon \\
\hline $\begin{array}{l}77-4-17,5 \\
12\end{array}$ & $\begin{array}{l}\text { Nbk. } 408 \\
\text { Wunsch 1997/1998, } \\
\text { No. } 15\end{array}$ & J. M. Shemtob & Babylon \\
\hline Sp.521 & BM 34402 & Spartali \& Co. & N/A [Babylon] \\
\hline $79-7-30,33$ & $\begin{array}{l}\text { Wunsch 2000a, } \\
\text { No. } 209\end{array}$ & J. M. Shemtob & Babylon \\
\hline $81-4-28,251$ & BM 40706 & $\begin{array}{l}\text { H. Rassam } \\
\text { (excavations) }\end{array}$ & $\begin{array}{l}\text { Jimjima } \\
\text { (southern Babylon) }\end{array}$ \\
\hline $81-6-25,40$ & Dar. 214 & Spartali \& Co. & Babylonia \\
\hline $81-7-1,341$ & BM 42581 & $\begin{array}{l}\text { H. Rassam } \\
\text { (excavations) }\end{array}$ & N/A \\
\hline $\begin{array}{l}81-8-30,265+394 \\
+831\end{array}$ & Nielsen 2010, No. 2.b & $\begin{array}{l}\text { H. Rassam } \\
\text { (excavations) }\end{array}$ & $\begin{array}{l}\text { Babylon: } 265,394 \\
\text { N/A: } 831 \text { [Babylon] }\end{array}$ \\
\hline $\begin{array}{l}84-2-11, \quad 111 \\
115\end{array}$ & $\begin{array}{l}\text { Dar. } 133 \\
\text { Dar. } 181\end{array}$ & Spartali \& Co. & N/A \\
\hline $\begin{array}{l}88-4-19, \quad 12 \\
21\end{array}$ & $\begin{array}{l}\text { Nielsen } 2010 \text {, No. } 3 \\
\text { Nielsen } 2010 \text {, No. } 2 . a\end{array}$ & N/A & N/A \\
\hline $98-5-14, \quad 469$ & Dubsar 11, No. 44 & S. A. Turabian & N/A [Borsippa] \\
\hline $99-4-15, \quad 347$ & BM 85540 & I. E. Gejou & N/A [Borsippa] \\
\hline 1901-10-12, 531 & BM 94878 & I. E. Gejou & N/A [Borsippa] \\
\hline 1920-12-13, 1 & Jursa, BaAr 1, No. 10 & I. E. Gejou & N/A \\
\hline $1930-7-25,2$ & BM $122180^{18}$ & D. Harpur & N/A \\
\hline
\end{tabular}

${ }^{18}$ Courtesy of John P. Nielsen. 18 
Unfortunately, little can be said about the provenance of tablets from other museum collections. The tablet from the Birmingham Museum and Art Gallery (BCM $57^{\prime} 76$ ) has been acquired either by antiquities trade or from a private collection - neither name of a provider nor provenance was registered (George, 1979, p. 121-122). Additionally, this is the only Neo-Babylonian contract in this collection acquired before 1981 when the so-called Wellcome collection arrived at the museum (Horowitz, 2000, p. 309; for the edition of the texts from the Wellcome collection see: Jursa, 1997).

Nothing more can be said about the tablet from the Royal Ontario Museum (ROM 910x209.387) apart from the fact that it was acquired prior to 1910 (Krabbenhøft, 2006) and that the Neo-Babylonian tablets registered within the same lot, i.e., No. 209, have been drafted in Babylon, Isin, Nippur, and Uruk (ROMCT 2, p. XVII-XVIII).

The Metropolitan Museum of Art purchased two tablets among two significant acquisitions made in 1879 and 1886. The first tablet, MMA 79.7.30, was purchased from J. M. Shemtob, the dealer already mentioned above in the connection to the British Museum to which he also sold tablets from Babylon. All of 79.7 tablets come from the Egibi archive; hence their provenance is presumably Babylon (CTMMA 3, p. XI, 83). The second tablet was purchased by the Reverend William Hayes Ward in 1886 together with ca. 450 other tablets. Neo-Babylonian tablets from this collection were drafted mostly in Babylon and Sippar, but no conclusion regarding the provenance of our tablet MMA 86.11.466 could be met.

The two tablets from the Vorderasiatisches Museum - VAT 3014 and VAT 4919 - were purchased on the antiquities market prior to the Koldewey's excavations in Babylon (1899-1917). Arthur Ungnad distinguished 13 dealers from whom Vorderasiatisches Museum bought Neo-Babylonian tablets published in VS 3-6 (VS 6, p. XII). None of their names was recorded, neither the provenances. Both our tablets come from the same 'source' but are separated into two acquisitions. Following Ungnad's numeration, these are VIb and VIf. VIb is a lot of 203 tablets. The majority of them was drafted in Babylon, and probably this entire acquisition is a single archive unearthed in that city (Jursa, 2005, p. 69-70). VIf consists of only a single tablet (VAT 4919 under discussion); therefore nothing can be said about its place of origin.

There are no registers to describe the provenance of the last tablet, i.e., NBC 6193, housed in the Yale Babylonian Collection. It belongs to the Nies Babylonian Collection (NBC) which together with Goucher College Cuneiform Inscriptions (GCCI), Newell Collection of Babylonian Texts (NCBT), Morgan Library Collection (MLC), and original Yale Babylonian Collection (YBC, founded in 1910) are now the biggest cuneiform collection in the United States - Yale Babylonian Collection. Due to antiquarian origin of this collection, nothing can be said about the provenance of the tablet, and unfortunately, no name of the dealer was recorded (Beaulieu, 1994, p. VII-X, 4). The collection was founded in 1922 (Beaulieu, 1994, p. VIII), but there is no information as to when particular tablets were acquired. 
Table 3. Information about the acquisition of tablets from other collections

\begin{tabular}{|l|l|l|l|}
\hline \multicolumn{1}{|c|}{ Museum No. } & \multicolumn{1}{|c|}{ Text } & \multicolumn{1}{c|}{ Purchased by } & \multicolumn{1}{c|}{ Provenance } \\
\hline $\begin{array}{l}\text { Birmingham Mus. and Art Gallery } \\
\text { BCM 57'76 }\end{array}$ & $\begin{array}{l}\text { George, Iraq 41 } \\
(1979), \text { No. 49 }\end{array}$ & N/A & N/A \\
\hline $\begin{array}{l}\text { Royal Ontario Museum } \\
\text { ROM 910x209.387 }\end{array}$ & ROMCT 2, 1 & N/A & N/A \\
\hline $\begin{array}{l}\text { Metropolitan Museum of Art } \\
\text { MMA 79.7.30 }\end{array}$ & CTMMA 3, 65 & $\begin{array}{l}\text { J. M. Shemtob } \\
\text { (purchased from) }\end{array}$ & Babylon \\
MMA 86.11.466 & CTMMA 3, 151 & W. H. Ward & N/A \\
\hline $\begin{array}{l}\text { Vorderasiatisches Museum } \\
\text { VAT 3014 (Ungnad's VIb) }\end{array}$ & VS 3, 17 & N/A & N/A [Babylon] \\
VAT 4919 (Ungnad's VIf) & VS 5, 1 & N/A & N/A \\
\hline Yale Babylonian Collection & & N/A & N/A \\
NBC 6193 & YOS 19, 57 & N/A & \\
\hline
\end{tabular}

To sum up, based on the data gathered from museum collections, 20 out of 36 tablets under discussion were presumably unearthed in Babylon (17 explicite ${ }^{19}, 3$ implicite), further three come from Borsippa (implicite), and 13 tablets have no assumed provenance ${ }^{20}$. It is also important is that none of these tablets proved to come from the area of Kish which once again emphasises the difference between 'place of issue' and 'provenance'.

\section{Solving the case: internal criteria}

Let us now proceed with analysis of the content of tablets under discussion. As it was mentioned earlier, internal criteria might be the key element in the quest for establishing provenance of a particular tablet. The prime step to be taken while reviewing the content of each tablet is to search for its archival attribution. If a document cannot be linked to any known archive based on sole prosopography, it is possible to search for secondary hints within a text which might allude necessary connection (e.g., mention of a particular temple or well-documented prosopography). For the reader's convenience, the analysis will be conducted in certain groups distinguished during the preliminary reading of the sources. Accession numbers are replaced here with standard texts sigla, i.e., museum numbers for unpublished texts and copies or editions sigla for already published tablets. Concordance between accession numbers and texts' sigla can be found in Tables 2. and 3., and within the underneath description.

\footnotetext{
19 Assuming that the provenance of the Egibi archive (Babylon) is certain.

${ }^{20}$ Of them four tablets from 84-2-11 and 88-4-19 collections are highly probable to come from Babylon based on the number of tablets related to it in these acquisitions.
} 


\section{Tablets with archival attribution}

\section{The Egibi archive (Babylon)}

The initial query showed that sixteen 'Kish' tablets are related to the Egibi archive; hence their provenance is Babylon (Jursa, 2005, p. 65-66). These are the eleven tablets from the British Museum's 76-11-17 collection (all but 76-11-17, 1036); the two tablets from the 77-4-17 collection; the tablet from the 79-7-30 collection; the tablet from the 81-6-25 collection; and the tablet from the 79.7 collection from the Metropolitan Museum of Art. I additionally divided them into six dossers contained within the archive. As some of the cases from the underneath dossiers (i.e., the business of Ishunnatu, the case of slave Barik-il, and the case of Arad-Gula and slave ${ }^{\mathrm{f}}$ Amtia) have been discussed in recently, my remarks regarding them will be limited to a minimum. Their attribution to the Egibi archive was proved elsewhere.

Table 4. Dossiers from the Egibi archive present in the 'Kish' tablets corpus

\begin{tabular}{|l|c|}
\hline \multicolumn{1}{|c|}{ Text } & \multicolumn{1}{|c|}{ Dossier } \\
\hline BM 30948 (76-11-17, 675) & \\
Camb. 330 (76-11-17, 773) & The business of fIshunnatu \\
Camb. 331 (76-11-17, 194) & \\
CTMMA 3, 65 (MMA 79.7.30) & The case of slave Barik-il \\
\hline Nbk. 346 (76-11-17, 880) & \\
Nbk. 408 (77-4-17, 5) & The case of Arad-Gula and slave ${ }^{\text {f Amtia }}$ \\
\hline Wunsch 1997/1998, No. 10 (76-11-17, 1648) & \\
Wunsch 1997/1998, No. 12 (76-11-17, 250) & The dealings of Itti-Marduk-balāțu \\
\hline Wunsch 1997/1998, No. 15 (77-4-17, 12) & \\
\hline Camb. 393 (76-11-17, 1628) & The dealings of Marduk-nāṣir-apli \\
\hline Abraham 2004, No. 17 (76-11-17, 356) & \\
BM 31363 (76-11-17, 1090) & \\
Dar. 214 (81-6-25, 40) & \\
Dar. 232 (76-11-17, 1779) & \\
Wunsch 2000a, No. 209 (79-7-30, 33) & The Nūr-Sîn annex of the Egibi archive \\
\hline BM 30621 (76-11-17, 348) & \\
\hline
\end{tabular}

The first dossier present in our 'Kish' tablets corpus is that of f Ishunnatu, a slave woman of the Egibis who conducted a tavern in Hursagkalamma. These are tablets Camb. 330 (76-11-17, 773; BM 31046), Camb. 331 (76-11-17, 194; BM 30467), BM 30948 (76-11-17, 675) $)^{21}$, and CTMMA 3, 65 (MMA 79.7.30) - all four drafted in Hursagkalamma. The whole dossier of fIshunnatu has been recently discussed by Gauthier Tolini (2013). IIshunnatu was a slave woman of Itti-Marduk-balāțu who represents

21 Unpublished copy: Bertin 2780. 
the third generation in the Egibi archive (Wunsch, 2000b, p. 102-105). He controlled the work of fIshunnatu (sometimes through his other slave, Kalbāya) as the family's interests slowly advanced towards the Kish area. It explains why these tablets were finally deposited within the main family's archive in Babylon. Additionally, one should know that all these tablets are presumably related to the tablet actually excavated in Kish, OECT 10, 239 (receipt for vats and furnishings; edited in Joannès, 1992; translation also in Tolini, 2013), which may indicate that some of the on-going documents were left on the site.

The second dossier is joined by the figure of another Egibi's slave named Barik-il whose case has been discussed by Cornelia Wunsch (2003, p. 67-71). He belonged to Itti-Marduk-balātu which is documented by a court case $\mathrm{Nbn} .1113^{22}$. Prior to his purchase by the Egibis Barik-il had run away from his original owner and Nbn. 1113 reveals his troubled past. Both our documents, i.e., Nbk. $346^{23}$ drafted in Kiš (76$11-17,880$ ), and $N b k .408^{24}$ drafted in Hursagkalamma $(77-4-17,5)$, are retroacts documenting the fate of Barik-il, and supposedly they were stored in the archive if any other litigations or claims were to appear in the future. After the purchase made by Itti-Marduk-balătu the documents were transferred to him. The area of Kish is presumably the place where the original owner of Barik-il lived. Her son had a theophoric element 'Zababa' (the main god of Kiš) in his name, which strengthens the bond between this family and their origins in the area of Kish (Wunsch, 2003, p. 71).

Three further tablets: Wunsch 1997/1998, No. 10 (76-11-17, 1648), Wunsch 1997/1998, No. 12 (76-11-17, 250), and Wunsch 1997/1998, No. 15, are part of the dossier dealing with the case of Arad-Gula and slave ${ }^{\mathrm{f} A m t i a}$. All three were written in Hursagkalamma. Their content documents the case of the female slave of Arad-Gula named ${ }^{\mathrm{f} A m t i a}$ who eventually has been bought by Itti-Marduk-balātu. Similarly to the case of Barik-il, these three tablets are retroacts, which happened to be deposited within the Egibi archive after conducting the purchase. The original owner of ${ }^{\mathrm{f}}$ Amtia conducted her case in Hursagkalamma as indicated by places of issue of each tablet. The fate of ${ }^{\mathrm{f}}$ Amtia and her owner was discussed in-depth by C. Wunsch (1997/1998, p. 68-70).

Camb. $393^{25}(76-11-17,1628)$ drafted in Hursagkalamma finishes the list of dealings of Itti-Marduk-balātu present in our corpus. It is a simple loan of silver where he appears as a creditor. Further relevant details and list of witnesses are unfortunately broken, but the name of the scribe is preserved. He was also a member of the Egibi family. Itti-Marduk-balātu has deposited this tablet in the archive in order to collect his debt in the future. This loan was written in the seventh year of Cambyses, i.e., a year after the establishing of the fIshunnatu's business. As such the tablet presents the active and not accidental presence of the Egibis in the Kish area which began and

\footnotetext{
22 Translation available at: https://nabucco.arts.kuleuven.be/item/28597

23 Translation available at: https://nabucco.arts.kuleuven.be/item/28534

24 Translation available at: https://nabucco.arts.kuleuven.be/item/30331

25 Translation available at: https://nabucco.arts.kuleuven.be/item/29425
} 
developed during the reign of Cambyses. Other texts show that it continued well into the reign of Darius.

Another five tablets are related to the dealings of Marduk-nāṣir-apli, the fourth generation in the Egibi archive (Wunsch, 2000b, p. 106-114). Abraham 2004, No. 17 (7611-17, 356) written in Hursagkalamma is a summon to settle the payment owed to Marduk-nāșir-apli. Debtor was supposed to come to Babylon to reach the agreement with Marduk-nāșir-apli regarding this case. This tablet has been deposited in the archive for Marduk-nāșir-apli in order to collect outstanding money in the future. Note that all four witnesses were from the families present mainly in Babylon (Ēpeš-ili ${ }^{26}$, Nabāya, Nappāhu, and Sagdidi; Wunsch, 2014, p. 304, 307-308). One could ask if they accompanied Marduk-nāșir-apli in Hursagkalamma in bonding the debtor to settle the payment?

BM 31363 (76-11-17, 1090) ${ }^{27}$ written in Hursagkalamma is a rental of a house by Marduk-nāṣir-apli to a certain individual. It confirms a fact known from tablets written elsewhere that Egibi's owned several real estates in the area of $\mathrm{Kish}^{28}$. Dar. $214(81-6-25,40)^{29}$ is an exchange document in the form of a promissory note written in Hursagkalamma. Marduk-nāșir-apli owed dates in exchange for an unidentified object. Dar. $232(76-11-17,1779)^{30}$ drafted in Hursagkalamma is a purchase of a donkey by one individual from another. Marduk-nāșir-apli acted here as a scribe. The reasoning behind the deposition of this document within his archive is puzzling ${ }^{31}$. In the text Wunsch 2000a, No. 209 (79-7-30, 33) written in Hursagkalamma Marduk-nāșir-apli purchased a field. Its exact localisation was not described (except that it was 'between the gates') but based on the place of issue of this document, the area of Kish seems like a reasonable assumption. This document was deposited because it secured Marduk-nāṣir-apli's ownership of this land and attested his payment.

The last tablet related to the Egibi archive is BM 30621 (76-11-17, 348) written in Hursagkalamma. It comes from the Nūr-Sîn family archive which was partially transferred to the Egibi archive when Itti-Marduk-balātu married ${ }^{\mathfrak{N}}$ Nūptāya, the daughter of Iddin-Marduk, son of Iqī̌sāaya, descendant of Nūr-Sîn family (Jursa, 2005, p. 65). It is a loan of silver with a pledge of a house where the member of the Nūr-Sin family is the creditor. One cannot determine why this particular tablet was moved to the Egibi archive.

\section{The archive of Bēl-ẹtir, the descendant of Mișirāya (Babylon?)}

The existence of this small archive of three tablets, all written in Kiš during the reign of Šamaš-šumu-ukīn, was recognised by John P. Nielsen (2010). It is focused around Bēl-êtịr, the descendant of Miṣirāya. Nielsen 2010, No. 2a (88-4-19, 21), and

\footnotetext{
${ }^{26}$ I chose this reading of the name instead of traditional Eppēš-ilī based on: Thissen, 2014, p. 147-148.

27 Unpublished copy: Bertin 2772.

28 For other Egibi’s houses in Hursagkalamma see: CTMMA 3, p. 126-127, 131.

29 Translation available at: https://nabucco.arts.kuleuven.be/item/31201

30 Translation available at: https://nabucco.arts.kuleuven.be/item/29377

31 Check Abraham, 1995 for other Marduk-nāṣir-apli's scribal activities.
} 
Nielsen 2010, No. 2b (81-8-30, $265+394+831)$ are two purchases of land in Kiš by Bēl-êtir from the same person. Nielsen 2010 , No. $3(88-4-19,12)$ is a lease of sheep. Based on the fact that Nielsen 2010, No. 2b probably come from Babylon (see: table 2) Nielsen put forward an interesting theory that Bēl-êtir ran away to Babylon during the Šamaš-šumu-ukīn's revolt (652-648 BC) to find shelter (Nielsen, 2010, p. 104). For what can be said from these three tablets, Bēl-êtir conducted his dealings solely in Kiš and no connections to Babylon or other cities can be drawn. However, Nielsen's theory built around 'archaeological' data, the coincidence of historical events and geography (closeness of Babylon), in my opinion, remains valid.

\section{The Gahal archive (Babylon)}

The two tablets from the 84-2-11 collection belong to the Gahal archive, which based on internal evidence is supposed to come from Babylon (Jursa, 2005, p. 67-68). It is possible that the Gahal family from Hursagkalamma and the Gahal family from Babylon was the very same family but so far no direct connection between them has been found (Jursa, 2005, p. 105-106). Dar. 133 (84-2-11, 111) ${ }^{32}$ was written in Kiš. It is a receipt of a payment of a debt owed by two brothers, Murašû and Tabnēa, sons of Aplāya, descendants of Gahal. Tabnēa's part is paid off by his other brother, Nabû-šumu-ukīn. The document contains a clause 'each has taken one (copy of the document)', thus we may safely assume that the tablet deposited in the archive in Babylon was one of such copies. We can go even further and presume that it belonged to Tabnēa as he is the prominent figure within the preserved part of the archive. Dar. $181(84-2-11,115)^{33}$ written in Hursagkalamma is another record of the debt owed by Tabnēa. The creditor was also a member of the Gahal family - one can only wonder if he was a member of Babylon's or Hursagkalamma's branch of this kin group. We can find two names with theophoric element 'Zababa' among witnesses, which reflects characteristic onomasticon of the people from the area of Kish. We do not know why Tabnēa chose Hursagkalamma as his place of business but another tablet from his archive written in Babylon, BE 8/1, 105, documents an income from the field in Harrān-Kiš. It seems then that Gahals tried to spread their influence outside Babylon and towards the Kish area.

\section{The Sîn-ilī archive (Babylon)}

One tablet from the Vorderasiatisches Museum in Berlin, VS 3, 17 (VAT 3014) written in Hursagkalamma, belongs to the well-documented archive of the Sîn-ili family which, based on internal evidence, comes from Babylon (Jursa, 2005, p. 6971). This document imposes an imittu (assessed rent) and other material obligations

\footnotetext{
${ }^{32}$ Transliteration available at: http://www.achemenet.com/en/item/?/3349245=Strassmaier\%20--Inschriften \%20von\%20Darius\&l=a\&c=1\&t=1.4/6/24/1/1655236

${ }_{33}$ Transliteration available at: http://www.achemenet.com/en/item/?/3349245=Strassmaier\%20--Inschriften\%20von\%20Darius\&l=a\&c=1\&t=1.4/8/24/1/1656121
} 
on a specific date gardener who rented an orchard from Țābia, son of Nabû-aplu-iddin, the descendant of Sîn-ilī. In the light of the archive under the discussion the main interest of the Sîn-ili family was agriculture. They owned multiple date gardens around Babylon, and this in Hursagkalamma was one of them. The tablet was deposited within the archive in order to collect future obligations from the tenant gardener. Based on the place of issue, it was probably written during the imposition of the imittu in the orchard in Hursagkalamma, and after that, it was transferred to the family's archive in Babylon. Note also the document VS 4, 20 written in Babylon, which documents a purchase of dates made by Țābia in Kiš.

\section{The Galläbu archive (Borsippa)}

The tablet from the 99-4-15 collection written in Hursagkalamma belongs to the archive of the Gallābu family from Borsippa (Jursa, 2005, p. 82-83). BM 85540 (99$4-15,347$ ) is an obligation to bring two empty vats to Borsippa to the member of the Gallābu family. As Gallābus were engaged in prebendary beer brewing it is possible that these vats were to be used in this process (Jursa, 2010, p. 222; Zadok, 2009, p. 271). The tablet was deposited within the archive in Borsippa in order to secure the future execution of the obligation.

\section{The Mannu-gērûšu archive (Borsippa)}

Our last tablet with a certain archival attribution is Dubsar 11, No. 44 (98-5-14, 469) written in Hursagkalamma. It belongs to the archive of Mannu-gērûšu family from Borsippa. It concerns an obligation to be delivered to Borsippa to the member of the Mannu-gērûšu family - a situation similar to that observed in BM 85540 (Zadok, 2009, p. 150). Once again, the tablet could have been deposited to oblige the burdened person to resolve the obligation.

\section{Tablets without archival attribution}

Here I will discuss tablets that, to the best of my knowledge, do not have any archival attribution, hence establishing their provenance based on internal criteria is very limited if not impossible. Two kinds of obstacles occurred during their analysis. Either these texts are prosopographically separated from all other known tablets, or they are too fragmentary to bear necessary information. As far as these tablets are concerned, future development of prosopographical databases like Prosobab (Waerzeggers, Groß, et al., 2019) or publications similar to Nielsen's prosopography of the Early Neo-Babylonian period (2015) could help us solve these problems.

AOATS 4, No. 77 (76-11-17, 1036) was written in Hursagkalamma. It is a loan of silver with a pledge. It comes from the 'Egibi collection' in the British Museum. However, there are no traces which leading to the incorporation of this document into the Egibi archive. No Egibis or Nūr-Sîns are present among contracting parties or 
witnesses and there are no prosopographical links to any other recognised archive, not to mention the material from the Ashmolean Museum.

Waerzeggers 2003/2004, No. 5 (1901-10-12, 531) is a pledge of a house written in Kiš during the revolt of Šamaš-erība. The house was situated 'next to the temple of Adad'. We do not know about the existence of the temple of Adad in Kiš or Hursagkalamma. If the pledged house was indeed in Kiš, then this is the first and only attestation of this temple. When it comes to prosopography of this document, it is separated from the rest of the known archives.

Jursa, BaAr 1, No. 10 (1920-12-13, 1) is a deposit document written in Hursagkalamma during the reign of Artaxerxes. No archival attribution and no other prosopographical links can be established in its regard. One should notice that the deposited silver came from 'the treasury of Bēl'; hence it may be somehow connected to Babylon.

BM 122180 (1930-7-25, 2) is a well-preserved purchase of land drafted in Hursagkalamma which prosopography is separated from the other tablets. It is a later copy of a document written during the reign of Kandalānu. The density of preserved tablets from this period is much lower than that from the 'long sixth century' and that might be the reason of not linking this text to any known archive. Its year of acquisition, i.e., 1930, creates possibility that this tablet in fact comes from the Oxford-Field excavations but one have to bear in mind that it was acquired from the small private collection, hence it is not known how long it has been there. Secondly, it is completely prosopographically separated from the rest of the Ashmolean material, thus it is hardly possible that it was excavated during the aforementioned mission.

George, Iraq 41, No. 49 (BCM 57'76) is a summon contract written in Hursagkalamma during the reign of Artaxerxes. The obliged person is supposed to escort an individual to Hursagkalamma. We know the destination of their journey but not its starting point, and then we cannot speculate about the city where this tablet could have been deposited if it was not in Hursagkalamma itself.

ROMCT 2, 1 (ROM 910x209.387) is a purchase of a female slave written in Kiš. Once again this text, despite its perfect preservation, has no prosopographical links to the other known tablets. What brings attention is that both contracting parties and three out of four witnesses do not have Babylonian names (Zadok, 2003, p. 512, 525).

VS 5, 1 (VAT 4919) is a purchase of a group of three(?) individuals by two gentlemen without patronymics given. The tablet was written in Hursagkalamma during the reign of Sennacherib. It is a very early text, hence it might be a retroact or later copy. It is a shame that no archival links could be established in its regard.

YOS 19, 57 is a receipt for payment of a house written in Kiš. The exact localisation of the house was not given, but based on the place of issue one cannot exclude Kiš itself. No prosopographical links to other known texts could be established. It is the only tablet drafted in Kiš in the NBC collection and its possible that it may be somehow joined to its material.

The remaining 'Kish' tablets are CTMMA 3, 151 (MMA 86.11.466), BM 34402 (Sp. 521), BM 40706 (81-4-28, 251), and BM 42581 (81-7-1, 341). Unfortunately, they are all to broken or fragmentary to analyse their content and prosopography. 
CTMMA 3, 151 issued in Hursagkalamma is a fragment of a loan of silver or quittance. Few names preserved, but full patronymics are missing. BM 34402 written in Hursagkalamma is a small fragment of the reverse with a few witnesses' names preserved. The readable fragment ends with the formula 'the nail of female [*her name* was pressed instead of her seal]'; thus it was presumably a conveyance document with a woman as a buyer. Among witnesses, there is '[name], husband of Nūptāya' mentioned. One could wonder if this was Nūptāya, the wife of Itti-Marduk-balātu, the descendant of Egibi, and that in result, her husband was present during this purchase. Based on the fact that there are some tablets from the Egibi archive within the Sp. collection it is possible but in no means certain. BM 40706 is a fragment of a contract(?) for barley written in Hursagkalamma. The name of Nidintu is mentioned on the obverse and apart from that, only the name of the scribe, without filiation on the reverse, is preserved. There is a stamp seal on the upper edge (Nisaba 28, No. 305). Finally, BM 42581 is a small fragment of a contract for bricks written in Kiš. Member of the Ir'anni family is burden with an obligation and, unfortunately, no more relevant details are preserved.

\section{CONCLUSIONS}

To sum up, tablets outside the Ashmolean Museum collection, which have been written in Hursagkalamma or Kiš almost certainly were unearthed somewhere else. Two major sites of their origin were recognised, Babylon and Borsippa. When it comes to numbers, the provenance of 28 out of 36 tablets was established. Eight tablets could not be attributed to any other city due to lack of collections' data, and because they could not be attached to any known archive. The reason for that is their prosopographical separation from other tablets or their poor state of preservation. The provenance of 25 tablets is Babylon, and three others are from Borsippa. Nineteen provenances were established both on collections' data and archival attribution. The provenance of four tablets was confirmed solely on collections' data and the origin of five tablets was localised only thanks to their archival attribution.

In order to establish provenance of a particular tablet, all factors should be treated as complimentary. When archaeological data is inevitable, it should obviously be of the first relevance, but when it is missing, there are still some hints, both internal and external, which might lead to a satisfactory conclusion. However, out of every kind of evidence, archival attribution indeed turns out to be the most important factor when establishing a provenance.

When it comes to the content of documents under discussion, they reveal the economic interests of the citizens of Babylon in Borsippa in the area of Kish. It turns out that the majority of tablets come from the Egibi archive. Egibis owned there numerous real estates and conducted there their business. All these tablets are testimonies of vivid and dynamic socio-economic lives of entrepreneurial Babylonians in the Neo-Babylonian period. 
Table 5. Summary table

\begin{tabular}{|c|c|c|c|}
\hline Text & Place of issue & $\begin{array}{l}\text { Collection } \\
\text { provenance }\end{array}$ & $\begin{array}{c}\text { Archival } \\
\text { attribution }\end{array}$ \\
\hline Abraham 2004, No. 17 & Hursagkalamma & Babylon & Babylon (Egibi) \\
\hline BM 30621 & Hursagkalamma & Babylon & Babylon (Egibi) \\
\hline BM 30948 & Hursagkalamma & Babylon & Babylon (Egibi) \\
\hline BM 31363 & Hursagkalamma & Babylon & Babylon (Egibi) \\
\hline BM 34402 & Hursagkalamma & Babylon & $\mathrm{N} / \mathrm{A}$ \\
\hline BM 40706 & Hursagkalamma & Babylon & $\mathrm{N} / \mathrm{A}$ \\
\hline BM 42581 & Kiš & N/A & $\mathrm{N} / \mathrm{A}$ \\
\hline BM 85540 & Kiš & Borsippa & Borsippa (Gallābu) \\
\hline BM 94878 & Hursagkalamma & Borsippa & $\mathrm{N} / \mathrm{A}$ \\
\hline BM 122180 & Hursagkalamma & N/A & $\mathrm{N} / \mathrm{A}$ \\
\hline Camb. 330 & Hursagkalamma & Babylon & Babylon (Egibi) \\
\hline Camb. 331 & Hursagkalamma & Babylon & Babylon (Egibi) \\
\hline Camb. 393 & Hursagkalamma & Babylon & Babylon (Egibi) \\
\hline CTMMA 3, 65 & Hursagkalamma & Babylon & Babylon (Egibi) \\
\hline CTMMA 3, 151 & Hursagkalamma & $\mathrm{N} / \mathrm{A}$ & $\mathrm{N} / \mathrm{A}$ \\
\hline Dar. 133 & Kiš & $\mathrm{N} / \mathrm{A}$ & Babylon (Gahal) \\
\hline Dar. 181 & Hursagkalamma & N/A & Babylon (Gahal) \\
\hline Dar. 214 & Hursagkalamma & $\mathrm{N} / \mathrm{A}$ & Babylon (Egibi) \\
\hline Dar. 232 & Hursagkalamma & Babylon & Babylon (Egibi) \\
\hline Dubsar 11, No. 44 & Hursagkalamma & Borsippa & $\begin{array}{c}\text { Borsippa } \\
\text { (Mannu-gērûšu) }\end{array}$ \\
\hline George, Iraq 41, No. 49 & Hursagkalamma & $\mathrm{N} / \mathrm{A}$ & $\mathrm{N} / \mathrm{A}$ \\
\hline Jursa, BaAr 1, No. 10 & Hursagkalamma & $\mathrm{N} / \mathrm{A}$ & $\mathrm{N} / \mathrm{A}$ \\
\hline Nbk. 346 & Kiš & Babylon & Babylon (Egibi) \\
\hline Nbk. 408 & Hursagkalamma & Babylon & Babylon (Egibi) \\
\hline Nielsen 2010, No. 2.a & Kiš & N/A & Babylon (Bēl-ēṭir) \\
\hline Nielsen 2010, No. 2.b & Kiš & Babylon & Babylon (Bēl-ēṭir) \\
\hline Nielsen 2010, No. 3 & Kiš & $\mathrm{N} / \mathrm{A}$ & Babylon (Bēl-ētir) \\
\hline ROMCT 2, 1 & Kiš & $\mathrm{N} / \mathrm{A}$ & $\mathrm{N} / \mathrm{A}$ \\
\hline AOATS 4, No. 77 & Hursagkalamma & Babylon & $\mathrm{N} / \mathrm{A}$ \\
\hline VS 3,17 & Hursagkalamma & Babylon & Babylon (Sîn-ilī) \\
\hline VS 5,1 & Hursagkalamma & $\mathrm{N} / \mathrm{A}$ & $\mathrm{N} / \mathrm{A}$ \\
\hline Wunsch 1997/1998, No. 10 & Hursagkalamma & Babylon & Babylon (Egibi) \\
\hline Wunsch 1997/1998, No. 12 & Hursagkalamma & Babylon & Babylon (Egibi) \\
\hline Wunsch 1997/1998, No. 15 & Hursagkalamma & Babylon & Babylon (Egibi) \\
\hline Wunsch 2000a, No. 209 & Hursagkalamma & Babylon & Babylon (Egibi) \\
\hline YOS 19, 57 & Kiš & $\mathrm{N} / \mathrm{A}$ & $\mathrm{N} / \mathrm{A}$ \\
\hline
\end{tabular}




\section{REFERENCES}

Abraham, K.

1995 The End of Marduk-nāșir-apli's Career as Businessman and Scribe: New Evidence from Unpublished Egibi Texts from the British Museum. In L. K. Van Lerberghe, A. Schoors (eds.), Immigration and Emigration within the Ancient Near East: Festschrift E. Lipiński (p. 1-9). Leuven: Peeters Publishers.

2004 Business and Politics under the Persian Empire: The Financial Dealings of Marduk-nāșirapli of the House of Egibi (521-487 B.C.E.). Bethesda: CDL Press.

Altavilla, S., Walker, C. B. F. (Nisaba 28)

2016 Late Babylonian Seal Impressions on Tablets in the British Museum, Part 2: Babylon and its vicinity. Winona Lake: Eisenbrauns.

Baker, H. D.

2004 The Archive of the Nappāhu Family. Vienna: Institut für Orientalistik der Universität Wien.

Beaulieu, P.-A.

1994 Late Babylonian Texts in the Nies Babylonian Collection. Bethesda: CDL Press.

(YOS 19)

2000 Legal and Administrative Texts from the Reign of Nabonidus. New Haven: Yale University Press

Clay, A. T. (BE 8/1)

1908 Legal and Commercial Transactions dated in the Assyrian, Neo-Babylonian and Persian Periods, chiefly from Nippur. Philadelphia: Department of Archaeology, University of Pennsylvania.

Clancier, P.

2009 Les bibliothèques en Babylonie dans la deuxième moitié du ler millénaire av. J.-C. Münster: Ugarit-Verlag.

Driel, G. van

1989 The British Museum 'Sippar' Collection: Babylonia 1882-1893. Zeitschrift für Assyriologie, 79, 102-117.

Frame, G.

2013 The Archive of Mušēzib-Marduk, Son of Kiribtu and Descendant of Sinn-nāsirir: A Landowner and Private Property Developer at Uruk in the Seventh Century BC. Dresden: ISLET-Verlag.

George, A. R.

1979 Cuneiform Texts in the Birmingham City Museum. Iraq, 41(2), 121-140.

George, A. R., Bongenaar, A. C. V. M.

2002 Tablets from Sippar: Supplementary bibliography etc. for Leichty, "Catalogues” VI-VIII, up to the end of 2000. Orientalia NS, 71(1), 55-156.

Gibson, McG.

1972 The City and Area of Kish. Coconut Grove: Field Research Projects.

Hackl, J.

2013 Materialien zur Urkundenlehre und Archivkunde der spätzeitlichen Texte aus Nordbabylo-

Horowitz, W. nien. Two volumes (unpublished $\mathrm{PhD}$ dissertation). University of Vienna.

2000 Astronomical Cuneiform Texts in the Birmingham City Museum. In A. R. George, I. L. Finkel (eds), Wisdom, Gods and Literature: Studies in Assyriology in Honour of W. G. Lambert (p. 309-314). Winona Lake: Eisenbrauns.

Jursa, M.

1997 Neu- und spätbabylonische Texte aus den Sammlungen der Birmingham Museums and Art Gallery. Iraq, 59, 97-174. 
1999 Das Archiv des Bēl-rēmanni. Istanbul and Leiden: Nederlands Historisch-Archaeologisch Instituut Te Istanbul.

(BaAr 1)

2002 Florilegium babyloniacum: Neue Texte aus hellenistischer and spätachämenidischer Zeit. In C. Wunsch (ed.), Mining the archives: Festschrift for Christopher Walker on the occasion of his 60th birthday, 4 October 2002 (p. 107-130). Dresden: ISLET-Verlag.

2005 Neo-Babylonian Legal and Administrative Documents: Typology, Contents and Archives. Münster: Ugarit Verlag.

2010 Aspects of the Economic History of Babylonia in the First Millennium BC. Economic Geography, Economic Mentalities, Agriculture, the Use of Money and the Problem of Economic Growth. Münster: Ugarit Verlag.

Krabbenhøft, R. W.

2006 Accession Numbers of the Royal Ontario Museum. Cuneiform Digital Library Notes, 2006:1. Online: https://cdli.ucla.edu/pubs/cdln/php/single.php?id=5

Leichty, E. (CBT 6)

1986 Catalogue of the Babylonian Tablets in the British Museum, vol. 6: Sippar 1. London: The British Museum Press.

Leichty, E. Finkel, I. L. Walker, C. B. F. (CBT 4, CBT 5)

(in preparation) Catalogue of the Babylonian Tablets in the British Museum, vol. 4-5. Münster: Zaphon.

Leichty, E., Finkelstein, J. J., Walker, C. B. F. (CBT 8)

1988 Catalogue of the Babylonian Tablets in the British Museum, vol. 8: Sippar, 3. London: The British Museum Press.

Moorey, P. R. S.

1978 Kish Excavations 1923-1933. Oxford: Clarendon Press.

McEwan, G. J. P. (ROMCT 2)

1982 The Late Babylonian Tablets in the Royal Ontario Museum. Toronto: Royal Ontario Museum.

(OECT 10)

1984 Late Babylonian Texts in the Ashmolean Museum. Oxford: Clarendon Press.

Neugebauer, O.

1955 Astronomical Cuneiform Texts. New York: Springer Science + Business Media.

Nielsen, J. P.

2010 Three Early Neo-Babylonian Tablets Belonging to Bēl-ētir of the Miṣirāya Kin Group. Journal of Cuneiform Studies, 62, 95-104.

2015 Personal Names in Early Neo-Babylonian Legal and Administrative Tablets, 747-626 B.C.E. Winona Lake: Eisenbrauns.

Panayotov, S. V., Wunsch, C.

2014 New Light on George Smith's Purchase of the Egibi Archive in 1876 from the Nachlass Mathewson. In M. J. Geller (ed.), Melammu: The Ancient World in an Age of Globalization (p. 191-215). Online: http://edition-open-access.de/proceedings/10/index.html [Accessed June 20, 2019]

Pedersén, $\mathrm{O}$.

2005 Archive und Bibliotheken in Babylon: die Tontafeln der Grabung Robert Koldeweys 18991917. Saarbrücken: Saarländische Druckerei und Verlag.

Sack, R. H. (AOATS 4)

1972 Amēl-Marduk, 562-560 B.C.: A Study based on Cuneiform, Old Testament, Greek, Latin and Rabbinical Sources. Neukirchen-Vluyn: Kevelaer and Neukirchener Verlag.

Sandowicz, M. (Dubsar 11)

2019 Neo-Babylonian Dispute Documents in the British Museum. Münster: Zaphon.

Sigrist, M. Zadok, R. Walker, C. B. F. (CBT 3)

2006 Catalogue of the Babylonian Tablets in the British Museum, vol. 3. London: The British Museum Press. 
Spar, I., Dassow, E. von (CTMMA 3)

2000 Cuneiform Texts in the Metropolitan Museum of Art, vol. 3: Private Archive Texts from the First Millennium B. C. New York: Brepols Publishers.

Stolper, M.

1984 The Neo-Babylonian Text from the Persepolis Fortification. Journal of Near Eastern Studies, 43(4), 299-310.

1990 Tobits in Reverse: More Babylonians in Ecbatana. Archaeologische Mitteilungen aus Iran, $23,161-176$.

Strassmaier, J. N. (Nbn.)

1889 Inschriften von Nabonidus, König von Babylon (555-538 v. Chr.). Leipzig: Verlag von Eduard Pfeiffer.

$(N b k$.)

1889 Inschriften von Nabuchodonosor, König von Babylon (604-561 v. Chr.). Leipzig: Verlag von Eduard Pfeiffer.

(Camb.)

1890 Inschriften von Cambyses, König von Babylon (529-521 v. Chr.). Leipzig: Verlag von Eduard Pfeiffer.

(Dar.)

1897 Inschriften von Darius, König von Babylon (521-485 v. Chr.). Leipzig: Verlag von Eduard Pfeiffer.

Thissen, $\mathrm{C}$.

2014 Studies in Neo-Babylonian Onomastics: the Use of the Sign DU். Akkadica, 135(2), 145 171.

Tolini, G.

2013 Between Babylon and Kiš: The Economic Activities of Ishunnatu, a Slave Woman of the Egibi Family (Sixth Century B.C.). Online: https://refema.hypotheses.org/766 [Accessed June 20, 2019].

Ungnad, A. (VS 3)

1907 Vorderasiatische Schriftdenkmäler, 3. Leipzig: J. C. Hinrichs'sche Buchhandlung. (VS 4)

1907 Vorderasiatische Schriftdenkmäler, 4. Leipzig: J. C. Hinrichs’sche Buchhandlung. (VS 5)

1908 Vorderasiatische Schriftdenkmäler, 5. Leipzig: J. C. Hinrichs’sche Buchhandlung. (VS 6)

1908 Vorderasiatische Schriftdenkmäler, 6. Leipzig: J. C. Hinrichs’sche Buchhandlung. Waerzeggers, C.

2003-2004 The Babylonian Revolts Against Xerxes and the 'End of Archives'. Archiv für Orientforschung, 50, 150-173.

2018 The Network of Resistance: Archives and Political Action in Babylonia Before 484 BCE. In C. Waerzeggers, M. Seire (eds), Xerxes and Babylonia: The Cuneiform Evidence (p. 89-133). Leuven: Peeters Publishers.

Waerzeggers, C., Groß, M. et. al.

2019 Prosobab: Prosopography of Babylonia (c. 620-330 BCE). Leiden University. Downloaded: https://www.prosobab.leidenuniv.nl/index.php

Wunsch, C. 1997-1998

Und die Richter berieten... Streitfälle in Babylon aus der Zeit Neriglissars und Nabonids. Archiv für Orientforschung, 44(45), 59-100.

2000a Das Egibi-Archiv. I: Die Felder and Gärten. Two volumes. Groningen: Styx Publications.

2000b Neubabylonische Geschäftsleute und ihre Beziehungen zu Palast- und Tempelverwaltungen: Das Beispiel der Familie Egibi. In A. C. V. M. Bongenaar (ed.), Interdependency of Institutions and Private Entrepreneurs: Proceedings of the Second MOS Symposium 
(Leiden 1998) (p. 95-118). Istanbul and Leiden: Nederlands Historisch-Archaeologisch Instituut te Istanbul.

2003 Urkunden zum Ehe-, Vermögens- und Erbrecht aus verschiedenen neubabylonischen Archiven. Dresden: ISLET-Verlag.

Zadok, R.

1985 Geographical Names according to New- and Late-Babylonian Texts. Wiesbaden: Dr. Ludwig Reichert Verlag.

2003 The Representation of Foreigners in Neo- and Late-Babylonian Legal Documents (Eighth through Second Centuries B.C.E.). In O. Lipschits, J. Blenkinsopp (eds), Judah and the Judeans in the Neo-Babylonian Period (p. 471-589). Winona Lake: Eisenbrauns.

2009 Catalogue of Documents from Borsippa or Related to Borsippa in the British Museum I. Messina: Di.Sc.A.M.

\section{Other markings}

BCM siglum of the cuneiform tablets in the Birmingham Museum and Art Gallery.

Bertin siglum of unpublished copies of cuneiform tablets in the British Museum drawn by G. Bertin.

BM siglum of the cuneiform tablets in the British Museum.

MMA siglum of cuneiform tablets in the Metropolitan Museum of Art.

NBC siglum of cuneiform tablets in the Nies Babylonian Collection.

ROM siglum of cuneiform tablets in the Royal Ontario Museum.

Sp. siglum of cuneiform tablets in the Spartali I collection in the British Museum.

VAT siglum of cuneiform tablets in the Vorderasiatisches Museum. THE PROVENANCE OF NEO-BABYLIONIAN LEGAL DOCUMENTS FROM 'KISH'
OUTSIDE THE ASHMOLEAN MUSEUM COLLECTION

Streszczenie

Większość znanych obecnie nowobabilońskich dokumentów prawnych i administracyjnych z Kisz pochodzi z wykopalisk prowadzonych na tym stanowisku przez wspólną misję Oxford i Field Museum (Chicago). Tabliczki znalezione w trakcie tych wykopalisk znajdują się obecnie w Ashmolean Museum w Oksfordzie. Zaskakujące jest zatem, że istnieje grupa blisko 40 tekstów, które znajdują się w innych kolekcjach muzealnych, a trafiły do nich głównie w ostatniej ćwierci XIX wieku. Rodzi się więc pytanie, skąd się tam wzięły, skoro było to ok. 30-50 lat przed wspomnianą misją? Przypuszczam, że nie odnaleziono ich w Kisz, wbrew temu o czym świadczą widniejące w ich tekstach sformułowania dotyczące miejsca spisania (niem. Ausstellungsort), ale że raczej zostały odkryte w pobliskim Babilonie lub Borsippie. Celem niniejszego artykułu jest zbadanie tej kwestii na podstawie analizy kryteriów zewnętrznych i wewnętrznych wspomnianej grupy tabliczek.

Kwerenda źródłowa zaowocowała sporządzeniem listy 36 tabliczek klinowych spisanych w Kiš lub Hursagkalamma (dwa miasta wchodzące w skład starożytnego regionu Kisz), które znajdują się w różnych kolekcjach muzealnych poza Ashmolean Museum. Najwięcej, bo aż 29, przechowywanych jest w British Museum w Londynie. W Metropolitan Museum of Art w Nowym Jorku oraz w Vorderasiatisches Museum w Berlinie znajdują się po dwie tabliczki. Birmingham Musuem and Art Gallery, Royal Ontario Museum oraz Yale Babylonian Collection posiadają po jednej tabliczce.

Zgromadzony materiał przebadano w dwójnasób, sprawdzając go pod kątem kryteriów zewnętrznych i wewnętrznych. Do kryteriów zewnętrznych zalicza się przede wszystkim informacje 
dotyczące pochodzenia danej tabliczki zawarte w rejestrach muzealnych. Takie dane mogły być odnotowane zarówno po wpłynięciu do muzeum tabliczek ze zorganizowanych wykopalisk, jak i przy zakupie artefaktów z obiegu antykwarycznego. W tym względzie szczególnie istotne okazały się dane pochodzące z British Museum. Do kryteriów wewnętrznych zalicza się głównie przynależność archiwalną danej tabliczki. Taką atrybucję określa się głównie na podstawie danych prozopograficznych.

Przeprowadzona analiza kolekcji muzealnych oraz treści poszczególnych tabliczek doprowadziła do ustalenia proweniencji 28 spośród 36 zgromadzonych dokumentów. Zgodnie z wynikiem badania 25 tabliczek najprawdopodobniej pochodzi z Babilonu, a trzy z Borsippy. Źródeł pozostałych ośmiu tabliczek nie udało się ustalić ze względu na ich prozopograficzne odseparowanie od reszty znanych dokumentów z okresu nowobabilońskiego lub z powodu ich złego stanu zachowania, który uniemożliwił uzyskanie wystarczających informacji. Proweniencja 19 tabliczek została potwierdzona przez dwa czynniki, czyli zarówno przez dane z kolekcji muzealnych, jak i przynależność archiwalną poszczególnych dokumentów. Miejsce pochodzenia czterech kolejnych tabliczek ustalono wyłącznie dzięki danym z kolekcji muzealnych, a pięciu ostatnich dokumentów oparto jedynie na ich przynależności archiwalnej.

Jeżeli chodzi o zawartość omówionych tabliczek, to obrazują one interesy prowadzone przez mieszkańców Babilonu i Borsippy w rejonie Kisz. W korpusie obecne są dokumenty pożyczek, kupna-sprzedaży, noty zobowiązań czy nawet sprawy sądowe. Wszystkie one wiązały gospodarczo mieszkańców wspomnianych miast z osobami osiadłymi w rejonie Kisz. Najwięcej dokumentów pochodzi z archiwum rodu Egibi z Babilonu. Wskazują na to, że zainteresowanie tej rodziny rejonem Kisz na dobre rozpoczęło się założeniem tam przez nich tawerny w czasach Kambyzesa II, a swoją obecność w tym regionie kontynuowali co najmniej do panowania Dariusza Wielkiego. Mieli tam domy, sady i prowadzili różnorodne interesy. Ogół analizowanych tekstów świadczy o żywym i dynamicznym socjo-ekonomicznym świecie Babilończyków w okresie nowobabilońskim. 